Przegląd Prawa Konstytucyjnego

- -ISSN 2082-1212--------

DOI 10.15804/ppk.2015.01.10

$-\mathrm{Nr} 1(23) / 2015$

\title{
Recenzja
}

\section{Carl Schmitt, Nauka o konstytucji, tytuł oryginalny: Verfassungslehre, przeł. Magdalena Kurkowska, Robert Marszałek, red. nauk., Marek A. Cichocki, Tomasz Krawczyk, Wydawnictwo Teologia Polityczna (Fundacja Świętego Mikołaja), Warszawa 2013, ss. 632}

Staraniem Wydawnictwa Teologia Polityczna i dra hab. Marka Cichockiego polski czytelnik otrzymał do ręki tłumaczenie na język polski jednej z najbardziej znanych prac prawniczych w kręgu germańskiej doktryny prawa konstytucyjnego, mianowicie Nauki o konstytucji prof. Carla Schmitta $(1888-1985)^{1}$. Poważną trudność dla recenzenta sprawia chociażby fakt, że monografia została pierwotnie wydana w 1928 r. i była przeznaczona dla niemieckiego czytelnika, ale i fakt, że stanowi dzieło klasyczne dla niemieckiej nauki prawa publicznego.

Znajomość publikacji Schmitta w polskiej nauce prawa w okresie istnienia II Rzeczypospolitej Polskiej była słaba, a ze zrozumiałych względów w okresie po 1945 r. zainteresowanie koncepcjami niemieckiego jurysty w polskiej nauce prawa było niemalże niezauważalne ${ }^{2}$. Omawiana pozycja przynależy do klasyki europejskiego konstytucjonalizmu, a o jej wyjątkowości - biorąc

1 Dla Czytelników niemieckojęzycznych dostępne były wydania tejże pracy wydawnictwa Duncker\&Humblot Gmbh.

2 Por. ustalenia Adama Wielomskiego, który podaje, iż w polskich przedwojennych publikacjach dotyczących prawa znajdujemy zaledwie kilka wzmianek o niemieckim juryście, a rezultatem kwerendy warszawskich bibliotek było odnalezienie zaledwie jednej książki niemieckiego naukowca, i to w tłumaczeniu na język francuski. A. Wielomski, Interpretacje 
pod uwagę pewne związki Schmitta z reżimem narodowo-socjalistycznym może świadczyć fakt, iż stanowiła istotny punkt odniesienia w trakcie prac nad ustawą zasadniczą państwa Izrael ${ }^{3}$. Cieszyć więc musi, że praca ta została opublikowana w polskim tłumaczeniu na rodzimym rynku wydawniczym.

Nauka o konstytucji stanowi próbę historiozoficznego zgłębienia fenomenu państwa, prawa publicznego, konstytucjonalizmu, jednocześnie będąc silnie osadzona w tradycji niemieckiej nauki o państwie i prawie. Monografia powstała przy tym w okresie, w którym Autor twierdził, iż państwo nowożytne przeżywa okres upadku, choć nadal istnieje „jedność polityczna”. Założenie, iż „polityczność” jest ściśle związana z państwem i prawem publicznym, jest jednym z podstawowych założeń „systemu”, który Schmitt chciał zbudować, pisząc omawianą książkę. Zrozumienie fenomenu „polityczności” i „jedności politycznej” zbiorowości pozwala na objaśnienie form ustrojowych, jakie powstawały w rozwoju dziejowym w Europie. Jednocześnie monografia stanowi podręcznik do prawa konstytucyjnego, w którym Autor zawarł wykład dotyczący pojęć właściwych tej gałęzi prawa.

Praca jest bardzo obszerna (przeszło 600 stron w recenzowanym wydaniu polskim) i została podzielona na IV części: I „pojęcie konstytucji”, II „państwo praworządne w granicach konstytucji”, III „polityczna część składowa konstytucji nowoczesnej”, IV „nauka o konstytucji związkowej”

Okres międzywojnia, w którym powstała Nauka o konstytucji, był okresem ze wszech miar specyficznym, kiedy trzy systemy ideologiczne (liberalizm demokratyczny, komunizm, faszyzm) konkurowały ze sobą, a ich zwolennicy pragnęli zorganizować ludzkie zbiorowości według zasad właściwych konkretnej ideologii. Ideologie natomiast implikowały konkretne rozwiązania w sferze ustrojowej ${ }^{4}$. Kolejną kwestią, która musiała odcisnąć swe piętno na pracy Schmitta, i z której trzeba zdawać sobie sprawę, był fakt, że nauka

Carla Schmitta na świecie i w Polsce, „Studia nad Faszyzmem i Zbrodniami Hitlerowskimi” 2011, t. XXXIII, s. $424-425$.

Por. J. Taubes, To Carl Schmitt. Letters and Reflections, New York 2013, s. 11.

4 Nawet jeżeli rewolucja faszystowska we Włoszech nie zniosła monarchii, a rewolucja nazistowska w Niemczech formalnie utrzymała w mocy Konstytucję Rzeszy Niemieckiej (Die Verfassung des Deutschen Reiches) z dnia 11 sierpnia 1919 r., to jednak - szczególnie w przypadku Niemiec - zmiany ustroju były rewolucyjne w treści, prowadząc do zmiany ustroju liberalno-demokratycznego w ustrój oscylujący w kierunku totalitarnego lub jawnie totalitarnego. Por. F. Ryszka, Państwo stanu wyjątkowego, Wrocław 1985, s. 208-212. 
prawa konstytucyjnego w latach dwudziestych XX w. była nauką stosunkowo młodą i z dość skromnym dorobkiem. Dostrzegł to sam Autor, wskazując na fakt, że katedra prawa konstytucyjnego na Uniwersytecie w Paryżu została powołana dopiero w 1835 r., skasowana wraz z zamachem stanu Napoleona III, reaktywowana w czasach III Republiki (1879). W początkach Republiki Weimarskiej nauka o konstytucji bardzo często wykładana była na uniwersytetach jako ogólna teoria państwa, czyli przedmiot bardziej właściwy naukom politycznym niż prawnym. Okoliczności te nadawały recenzowanej pracy cechę względnej pionierskości w okresie, gdy została pierwotnie opublikowana 5 .

Na pierwszych kartach swojej pracy C. Schmitt przekonuje, że „do zadań nauki o konstytucji należy raczej wykazanie, jak bardzo niektóre tradycyjne formy i pojęcia zależą od sytuacji wcześniejszych" (s. 18), co ewidentnie odróżnia analizę prawną Autora od wielu współczesnych prac o prawie konstytucyjnym, które rażą ahistorycznym ujęciem tematyki i w których jakby przyjęto, że obecne formy ustrojowe i instytucje prawne cechuje walor oczywistości i niemalże „odwieczności”, co znów właściwe jest pozytywizmowi prawniczemu, który krytyce poddawał niemiecki badacz prawa.

Schmitt rozpoczął swój wykład od próby zdefiniowania przedmiotu badawczego, a więc konstytucji jako takiej. Myliłby się ten, kto zakładałby, iż jest to prosty synonim „ustawy zasadniczej”. W recenzowanej pozycji znajdujemy istną mnogość definicji terminu „konstytucja”. Zależnie od kontekstu i przyjętych założeń wyjściowych „konstytucję” jurysta najczęściej rozumie jako „ogólną kondycję jedności politycznej i porządku społecznego określonego państwa [...] Państwo nie ma konstytucji, <zgodnie z którą> tworzy się i urzeczywistnia wola polityczna, ono jest konstytucją, a więc bytem, istniejącym stanem, statusem jedności i porządku” (s. 26-27). Definicja taka jest wyraźnie inspirowana naukami Arystotelesa, który państwo ujmował jako porządek właściwy dla współegzystencji ludzi zamieszkujących określony obszar:

- $\quad$ szczególny rodzaj porządku politycznego i społecznego, czyli po prostu formę konkretnego państwa (s. 28);

5 Por. E. Kennedy, Constitutional failure, Carl Schmitt in Weimar, Durham and London 2004, s. 122-123. 
- $\quad$ porządek, który wolę jednostek przekształca w całościową wolę państwa, jednocząc przy tym „członki” organizmu państwowego, czyli - powtarzając za F. Lassale - konstytucja jest siłą sprawczą państwa (s. 31);

- $\quad$ ustawę zasadniczą, czyli jednolity i zamknięty system najwyższych norm (konstytucja jako „norma norm”), gdzie konstytucja jest czymś normatywnym, „czystą powinnością”, aktem, który w epoce sporów o to, czy suwerenny jest monarcha, czy też lud, pozwolił na odpowiedź: suwerenna jest konstytucja (s. 32-33).

Dostrzegamy więc silną tendencję do relatywizacji pojęcia konstytucji, jak również jej charakteru prawnego: konstytucja może być formą umowy np. pomiędzy „stanami” lub „ludem” a monarchą, i znane są takie konstytucje, które expressis verbis określały same siebie jako umowy, np. konstytucja Wirtembergii („doskonałe obopólne porozumienie w następujących punktach" [1819], czy Saksonii [1831], lub też szczególną ustawą. Jeżeli dzisiaj nauka prawa skłonna jest wskazywać na konstytucje oktrojowane i uchwalone, a nie „umówione”, to zapewne dlatego, że konstytucja jako umowa była kompromisem, prawie zawsze o charakterze tymczasowego rozwiązania, który wcale nie rozstrzygał konfliktu pomiędzy stronami zawierającymi taką umowę. Znaczna część Nauki o konstytucji jest poświęcona właśnie tej kwestii, tzn. konstytucji jako umowie, i procesom historycznym, które towarzyszyły powstawaniu tych aktów. Nawet gdy C. Schmitt pisał o konstytucji jako ustawie zasadniczej, relatywizował to drugie pojęcie, wskazując na wielość definicji samej ustawy zasadniczej (por. s. 87 i n.).

Dodatkowo - i wątek ten pojawia się w publikacji bardzo często - akt ustrojodawczy może mieć zakres w gruncie rzeczy dość ograniczony. Schmitt widział rolę ustrojodawcy raczej jako podmiotu, który nadaje ostateczny kształt konstytucji - ustrojowi, ale ma ograniczony wpływ na esencję ustroju. Wiąże się to w przypadku Schmitta z poczynionym przez niego rozróżnieniem na „konstytucję” i „ustawę konstytucyjną”, gdzie ta pierwsza stanowiła esencję ustawy konstytucyjnej. W ujęciu formalnym ustawa zasadnicza miałaby więc być zbudowana $\mathrm{z}$ dwóch rodzajów norm: norm o fundamentalnym znaczeniu dla kształtu państwa i norm o charakterze drugorzędnym, które dopełniają i umożliwiają zastosowanie norm pierwszego rodzaju. Prawidłowa sytuacja, wydaje się, że tak należy odczytać przesłanie 
jurysty, to ustrój będący wytworem narodu (,jedność polityczna”), zweryfikowany doświadczeniami pokoleń, w którym rola ustrojodawcy sprowadza się właściwie do „aktualizacji” prawa konstytucyjnego. Czy wobec tego zmiana esencji ustroju jest możliwa? Schmitt stara się przekonać, że tak, ale tylko w drodze aktu o charakterze rewolucyjnym.

Carl Schmitt w swej monografii dokonał szczegółowej analizy wielu kwestii pozostających w sferze zainteresowania konstytucjonalizmu. Stosunkowo dużo miejsca poświęcił problematyce praw podstawowych. Źródła tych praw dopatrywał się w liberalnych rewolucjach XVIII w. ${ }^{6}$ i wyraźnie różnicował je z prawami zawartymi w ustawach zasadniczych, tzn. w tym ujęciu nie każda ochrona przed zmianą przez zwykłą ustawę musi oznaczać istnienie prawa podstawowego. Stąd też Schmitt postulował, by za prawa podstawowe uważać jedynie prawa przed- i ponadpaństwowe, a więc wynikające z ontycznego statusu człowieka jako takiego. Jeżeli dziś taki pogląd wydaje się niemalże truizmem, to powyższe ujęcie problemu w latach dwudziestych XX w. uznać należy jednak za oryginalne. Wśród tych praw podstawowych szczególne miejsce miało zajmować tzw. prawo do oporu, w aktualnie dominującej doktrynie praw człowieka zapomniane, a oznaczające ostateczny środek ochrony wszelkich praw podstawowych, „niezbywalny, choć niepodatny na zabiegi organizacyjne" (s. 275-277). Ciekawa jest ocena niemieckiego badacza dotycząca praw, które on określał mianem „socjalistycznych”, a które dziś niekiedy nazwane są mianem pozytywnych praw człowieka. Uważa on, że takowe prawa nie są absolutne, nie są bezgraniczne, gdyż jedynie struktura państwowa jest zdolna zagwarantować ich wykonanie, „co już relatywizuje prawo - jest ono uwarunkowane przez organizację, która ogarnia indywiduum, wskazuje mu jego miejsce, wyznacza i racjonuje roszczenia" (s. 284).

Kolejną kwestią w wykładzie niemieckiego badacza prawa, na którą warto zwrócić szczególną uwagę, jest wykład o parlamentaryzmie (s. 479-549). Czytelnik znajdzie w Nauce o konstytucji bardzo wnikliwą analizę form parlamentaryzmu i ewolucji funkcjonowania parlamentaryzmu w Anglii, Niemczech, Francji, ze szczególnym akcentem na omówienie parlamentaryzmu weimarskiego. W tej części książki nie znajdujemy krytyki nowocze-

6 Wcześniejsze zbiory praw, na czele z Magna Charta Libertatum (1215), były co najwyżej zbiorami praw baronów, szlachty, bardzo rzadko mieszczaństwa, i nie posługiwały się jednolitą kategorią „człowieka” jako podmiotu tychże praw. 
snego parlamentaryzmu, jaka cechowała np. znany tekst Autora pt. Duchowa $i$ historyczna sytuacja dzisiejszego parlamentaryzmu. Parlamentaryzm był pewną formułą „zrównoważenia i zrelatywizowania elementów formy państwowej”, która powstała w czasach sporów z rządem monarchicznym (s. 481, 484). Parlament jako ciało prawodawcze w ujęciu historycznym lansował projekt „parlamentaryzacji rządu”. Parlamentaryzm nadto był praktycznym rozwiązaniem problemu „rozrastania się” wspólnot politycznych, co powodowało trudności lub wręcz niemożność sprawowania władzy przez lud za pomocą instrumentów demokracji bezpośredniej. Zdaniem jurysty istotą liberalnego projektu politycznego był parlamentaryzm, jako odbicie debaty publicznej w sferze ustrojowej, gdzie racjonalne grupy wyborów wybierały na swoich reprezentantów utalentowanych przedstawicieli, którzy spotykali się w parlamencie, aby prowadzić racjonalną debatę i dyskusję, przekonując się do określonych rozwiązań za pomocą argumentów. Miał gwarantować dialektyczne i dynamiczne przezwyciężanie sprzeczności i odmiennych poglądów, tak by wykrystalizowała się „wola państwowa”. Parlamentaryzm, zdaniem niemieckiego uczonego, mógł prawidłowo funkcjonować, jeżeli u jego podstaw leżały „wykształcenie i posiadanie”. A przez prawidłowe funkcjonowanie rozumiał stan, w którym publicznie dyskutuje się opinie polityczne, gdzie istnieje mniejszość i większość, partia rządząca i opozycja, które starają się przekonać. Lud dyskutować nie jest w stanie, co najwyżej może odnosić się do pewnych kwestii przez aklamację lub negację (s. 490-502) ${ }^{8}$.

7 C. Schmitt, Duchowa i historyczna sytuacja dzisiejszego parlamentaryzmu, [w:] idem, Teologia polityczna i inne pisma, Warszawa 212, s. 141-226.

8 W innym swym dziele Duchowa i historyczna sytuacja dzisiejszego parlamentaryzmu Schmitt dodał, że tak pojętemu „parlamentaryzmowi dżentelmenów z połowy XIX wieku” ostateczny cios zadało powszechne prawo wyborcze, a wraz z tym pojawienie się populistycznych i klasowych partii masowych, które odwołały się do namiętności rzesz niewykształconych lub sfrustrowanych wyborców, a nie do ich racjonalnej oceny rzeczywistości: „poparcie mas zdobywają dzięki aparatowi propagandy, który odwołuje się przede wszystkim do konkretnych, namacalnych interesów i emocji” i dlatego „literatura poświęcona psychologii, technice i krytyce kształtowania opinii publicznej przez partie polityczne, jest dzisiaj bardzo obszerna", a opinie z pierwszej połowy XIX stulecia o racjonalnej debacie politycznej nie znajdują pokrycia w faktach w rzeczywistości XX w. Demokracja masowa zakłada identyczność rządzących i rządzonych, a dążenie to napotyka na swej drodze parlamentaryzm. W dzisiejszych parlamentach nie prowadzi się racjonalnej debaty, lecz deputowani 
Przechodząc do oceny całościowej pracy: twórczość C. Schmitta przeżywa okres wzmożonego zainteresowania, a wzrastająca liczba publikacji traktujących o poglądach niemieckiego prawnika z zakresu nauk politycznych wydaje się trwałym trendem - zarówno w polskiej literaturze, jak i zachodniej (szczególnie publikacje w języku angielskim i francuskim). Mimo tej popularności w naukach politycznych w polskiej nauce prawa analizy niemieckiego jurysty właściwie pozostawały niemalże nieznane, a liczba publikacji dotyczących prawniczego aspektu twórczości Schmitta co najmniej skromna. Wydaje się, że opublikowanie tłumaczenia Verfassungslehre może zmienić ten stan.

Styl wywodu C. Schmitta kojarzyć się może ze stylem twórczości Maxa Webera, z którym ten pierwszy bardzo często polemizował - w końcu tych dwóch wybitnych teoretyków prawa publicznego w niemieckiej nauce zajmowało się również zagadnieniami właściwymi socjologii czy historii, i wątki właściwe tym naukom dostrzegamy w ich analizach prawnych. Refleksja o prawie jest tutaj ściśle związana z refleksją filozoficzną, socjologiczną, historiozoficzną.

Nauka o konstytucji została napisana przeszło 80 lat temu, a mimo to zachowuje zadziwiającą aktualność. Gdyby pominąć wątki właściwe wyłącznie prawu konstytucyjnemu tzw. Republiki Weimarskiej, które nie zajmują objętościowo znów aż tak dużo miejsca w recenzowanej pracy, książka z powodzeniem stanowić może pomoc dydaktyczną dla nauki prawa konstytucyjnego, także dzięki oryginalności wielu ocen i poglądów zawartych w publikacji. Schmitt z pasją omówił instytucje właściwe tej gałęzi prawa i jest to wykład zupełnie inny niż ten właściwy Kelsenowskiej „czystej teo-

prześcigają się w populistycznych deklaracjach, a sama debata parlamentarna nabrała cech fikcyjności i gry pozorów, potwierdzając jedynie uzgodnienia wąskich gremiów kierowniczych zapadające w kuluarach. Współczesny parlamentaryzm doprowadził do tego, że decyzje zapadają w gabinetach liderów partyjnych oraz właścicieli banków i wielkich fabryk, przy ewentualnym współudziale przedstawicieli innych grup społecznych. C. Schmitt, Duchowa $i$ historyczna sytuacja dzisiejszego parlamentaryzmu, [w:] idem, Teologia polityczna, op.cit., s. 176-178. W ocenie niemieckiego prawnika w takim systemie debata, rozumiana jako forma ekspresji i sposób wypracowania kompromisowego stanowiska, nabrała cech fikcyjności, i w tym punkcie jego opinia odpowiada założeniom marksizmu-leninizmu, który również ujmował zachodnie demokracje jako formę mistyfikacji, służącą ukryciu rzeczywistej władzy kapitalistów. 
rii prawa”, zakładającej „naukę wolną od wartościowania”. Pojęcia prawne są pewnym wytworem myśli funkcjonującej w konkretnych warunkach historycznych i fakt ten został dobrze ukazany dzięki licznym dygresjom historycznym, jakie znajdziemy w publikacji. Kolejnym elementem właściwym Nauce... jest sposób analizy prawa konstytucyjnego, z którego wynika, że nauka o ustroju państwa to coś znacznie więcej niż opis struktury izb parlamentu czy regulaminów ich funkcjonowania. Kwestie te mają swoje znaczenie, lecz Schmitt stawia pytanie: czymże są kwestie proceduralne lub ogólnie ustawy konstytucyjne wobec zagadnienia jedności politycznej i istoty państwa jako takiego, a więc konstytucji?

Paweł Bała Uniwersytet Przyrodniczo-Humanistyczny w Siedlcach 